\title{
Lateral Ventricle Meningioma
}

National Cancer Institute

\section{Source}

National Cancer Institute. Lateral Ventricle Meningioma. NCI Thesaurus. Code C5302.

A mening ioma that affects the lateral ventricle of the brain. 